\title{
Changes in the Amino Acid and Protein Content of Jatropha Curcas Induced By Fusarium Oxysporum and Macrophomina Phaseolina
}

\author{
${ }^{1}$ Isalar, O.F., ${ }^{2}$ Nwaukwu, I.A. And ${ }^{1}$ Ataga, A.E. \\ ${ }^{I}$ Department of Plant Science and Biotechnology, Faculty of Biological Science, University of Port Harcourt, \\ Rivers state- Nigeria)
}

\begin{abstract}
Changes in the Amino acid and Protein content of Jatropha curcas induced by Fusarium oxysporum and Macrophomina phaseolina, was carried out using the Association of Official Analytical Chemist method. The Physic nut seeds (Jatropha curcas L) were collected from Federal College of Forestry, Jos, Plateau State. This was carried at the Mycology/Plant Pathology and Physiological Unit of the Department of Plant Science and Biotechnology, University of Port-Harcourt. The results of the total amino acids of the fungi inoculated and uninoculated control Jatropha curcas seeds showed that there was significant reduction $(P=0.05)$ in total amino acids of seeds inoculated with Fusarium oxysporum $(91.59 \mathrm{~g} / 100 \mathrm{~g}$ protein) and Macrophomina phaseolina $(90.41 \mathrm{~g} / 100 \mathrm{~g}$ protein) compared to uninoculated control $(93.23 \mathrm{~g} / 100 \mathrm{~g}$ protein). The changes in the amino acid and protein levels of the seeds as a result of the activities of these fungi are discussed.
\end{abstract}

Keywords: Amino acid content, Jatropha curcas, Pathogenic fungi, Protein content

\section{Introduction}

Jatropha plant has been found for using on different aspects in different communities in the world. It has been found that the plant is used as an ornamental purpose, chiefly in Africa and America, growing in gardens for their ornamental foliage and flowers. It is also commonly grown as a live hedge around agricultural fields as it can be easily propagated by seeds or branch cutting as is not browsed by goats or cattle. It can be cut or lopped at any desired height and is well adapted for hedges around agricultural fields.[1] (Gubitz et al, 1999). The most important uses of the plant is its use for biodiesel production.

Jatropha is often described as having a low nutrient requirement because it is adapted to growing in poor soils. However, growing a productive crop requires correct fertilization and adequate rainfall or irrigation. Equally, high levels of fertilizer and excessive irrigation can induce high total biomass production at the expense of seed yield. Unfortunately, there is insufficient data on response to fertilizer under different growing conditions for it to be possible to make specific recommendations for optimal crop nutrition. On wasteland in India,[2] Ghosh et al. (2007) found that 3.0 tonnes per ha of Jatropha seed cake (also known as "press" cake), containing 3.2 percent $\mathrm{N}, 1.2$ percent $\mathrm{P}_{2} \mathrm{O}_{5}$ and 1.4 percent $\mathrm{K}_{2} \mathrm{O}$, increased yields significantly when applied to young plants - by +120 percent and +93 percent at two different planting densities. A trial at the International Crops Research Institute for the Semi-Arid Tropics (ICRISAT) in India showed increasing yield with fertilization to an optimum level (T3), but that over-application depressed yields.

The optimum levels of inorganic fertilizers have been seen to vary with the age of the tree[3] (Achten, 2008). Site-specific fertilizer trials need to be established for trees of different ages and over a number of seasons. An analysis of the nutrient value of harvested fruit indicates the application rate of nutrients required to maintain soil fertility levels, assuming all other biomass is retained in the field. From the nutrient composition calculated by [4]Jongschaap et al. (2007), the fruit equivalent of 1.0 tonne of dry seed per ha removes 14.3-34.3 $\mathrm{kg}$ of $\mathrm{N}, 0.7-7.0 \mathrm{~kg}$ of $\mathrm{P}$, and $14.3-31.6 \mathrm{~kg}$ of $\mathrm{K}$ per ha. Mycorrhyzal soil fungi are generally known to improve a plant's ability to absorb mineral nutrients and water from the soil, and to increase drought and disease resistance. The Energy and Resources Institute (TERI) in India has developed mycorrhyzal inoculations for jatropha that improve germination and gives earlier fruiting and higher yields.[5] (Sharma 1977, cited Jongschaap, 2007) found increased uptake of $\mathrm{P}$ and micronutrients.

However, fungi growing on stored seeds, can reduce the germination rate along with loss in the quantum of carbohydrate, protein and total oil content, induces moisture content, free fatty acid content enhancing other biochemical changes of seeds. Due to its economic, nutritional and agricultural importance a study is carried out to find out the effect of the above fungi on the amino acid and protein content of Jatropha curcas seed. 


\section{Materials And Methods}

\subsection{Isolation and identification of fungi.}

The fungi used in this study Fusarium oxysporum and Macrophomina phaseolina were isolated from the apparently healthy seeds using the Standard Blotter method recommended by the international Seed Testing Association [6](ISTA, 1976 and Agar method [7](Klement and Voros, 1974). The fungi were identified under a Stereobinocular microscope based on their habit characteristics. Slides were made to confirm identification following descriptions by International Mycological Institude (IMI fungi Descriptions). Pure, single spore cultures of each fungi were obtained by growing them on Potato Dextrose Agar (PDA). The cultures were left in a sterile incubator at room temperature $\left(28 \pm 2^{\circ} \mathrm{C}\right)$ for $5-7$ days to allow for the growth of fungi and were used as inoculum.

\subsection{Inoculation of Seeds with Fungi}

Fifty grams of healthy Jatropha curcas seeds were weighed out into $250 \mathrm{ml}$ conical flasks, plugged with non-absorbent cotton wool and covered with foil and then autoclaved at $121^{\circ} \mathrm{C}$ for $15 \mathrm{mins}$ to eliminate any internal and external seed borne micro-organisms[8] (Ataga and Umechuruba,1997). After autoclaving the flasks were allowed to cool and $20 \mathrm{ml}$ of sterile distilled water was added to each flask and shaken gently to wet all the seeds, create humid and conducive environment. Each flask containing seeds was inoculated with a disc of 7 day old spores of each fungus of Fusarium oxysporum and Macrophomina phaseolina respectively obtained from the pure culture of isolated fungi from the infected seeds. This was carried out with a $1.5 \mathrm{~cm}$ diameter sterile cork borer.

The flasks were gently shaken for about 15 minutes to obtain uniform distribution of the mycelium among the seeds. The control flask, received the same treatment, but there was no fungi added to it. The entire flasks which include the fungi inoculated and uninoculated seeds were incubated at room temperature for 7 days. At the end of the incubation period, two flasks of each fungal treatment and one flask for control were harvested for biochemical analysis. The seeds in each flask were transferred into a pre-weighed watch glass, dried at $45^{\circ} \mathrm{C}$ for 24 hours and the spores and mycelia of the fungi removed by sieving [8] (Ataga and Umechuruba, 1997).

\subsection{Determination of Crude Protein by Kjeldahl Method}

The protein analysis was determined by kjedahl nitrogen method described by [9] Osborne and Voogt (1978). The stages are Digestion, Distillation and Titration

\subsubsection{Digestion}

Into $250 \mathrm{ml}$ conical flask, $0.1 \mathrm{~g}$ sample of inoculated and uninoculated seeds and $3 \mathrm{~g}$ digestion catalyst were placed and $20 \mathrm{mls}$ concentrated sulphuric acid was added. The flask was heated to digest the content from black to sky-blue colouration. The digest was cooled to room temperature and was diluted to $100 \mathrm{mls}$ with distilled water.

\subsubsection{Distillation}

$20 \mathrm{ml}$ diluted digest was measured into a distillation flask and the flask was held in place on an electrothermal heater hot plate. It was then attached to a liebig condenser, connected to a receiver adaptor containing $10 \mathrm{mls}$ 0f $2 \%$ boric acid indicator. $40 \mathrm{ml}$ of $40 \%$ sodium hydroxide was injected into the digest via a syringe attached to the arm of the mimo arm steel head until the digest became strongly alkaline. The mixture was heated to boil and the ammonia gas was collected via the condenser into the receiver beaker. The color of the boric acid changed from purple to greenish as ammonia distillate was introduced into the boric acid.

\subsubsection{Titration}

The distillate was titrated with $0.1 \mathrm{~N}$ Hydrochloric acid back to purple from greenish. The volume of Hydrochloric acid added to effect this change was recorded as the titre value.

$\mathrm{N}_{2}=\frac{\text { titre value X } 1.4 \times 100 \times 100}{10}$ $1000 \mathrm{mg} X$ weight of sample $X$ volume

$\%$ Crude protein $=\% \mathrm{~N}_{2} \mathrm{X}$ Conversion factor $(\mathrm{F})$

Where $\mathrm{N}_{2}=$ Crude Nitrogen, $\mathrm{F}=6.25$

\subsection{Determination of amino acid content amino acid extraction}

Modified AOAC Method 982.30, 2006 was followed in the extraction of the sample for the amino acid analysis. The dried and pulverized sample was made to be free of water by ensuring constant weight for a period of time in the laboratory the sample of $10.0 \mathrm{~g}$ was weighed into the $250 \mathrm{ml}$ conical flask capacity. The sample was deffated by extracting the fat content of the sample with $30 \mathrm{ml}$ of the petroleum spirit three times with 
soxhlet that was equipped with thimble. The sample was hydrolyzed three times for complete hydrolysis to be achieved.

The amino acid content of the sample was recovered by extracting with $30 \mathrm{ml}$ of the dichloro methane three times before concentrating to $0.1 \mathrm{ml}$. the concentrated extract was derivatised for volatility that is suitable for gas chromatography analysis

\subsubsection{Gas Chromatography Conditions for Amino Acids}

GC: $\quad$ HP 6890 Powered with HP ChemoStation Rev. A 09.01 [1206] software

Injection Temperature: Split Injection

Carrier Gas: Hydrogen

Flow Rate: $\quad 1.0 \mathrm{ml} / \mathrm{min}$

Inlet Temperature: $\quad 250^{\circ} \mathrm{C}$

Column Type: $\quad$ HP 5

Column Dimensions: $\quad 30 \mathrm{~m} \times 0.25 \mathrm{~mm} \times 0.25 \mu \mathrm{m}$

Oven program: $\quad$ Initial @ $60^{\circ} \mathrm{C}$

First Ramp @ $8^{\circ} \mathrm{C} / \mathrm{min}$ for $20 \mathrm{~min}$, maintained for $2 \mathrm{~min}$.

Second Ramp @ $12^{\circ} \mathrm{C} / \mathrm{min}$ for $6 \mathrm{mins}$, constant for $2 \mathrm{mins}$

Detector:

PFPD

Detector Temperature: $320^{\circ} \mathrm{C}$

Hydrogen Pressure: $\quad 20 p s i$

Compressed Air: $\quad 35 \mathrm{psi}$

\section{Results}

The results of the total amino acids of the fungi inoculated and uninoculated control Jatropha curcas seeds are presented in "Fig 1". There was significant reduction $(\mathrm{P}=0.05)$ in total amino acids of seeds inoculated with Fusarium oxysporum $(91.59 \mathrm{~g} / 100 \mathrm{~g}$ protein) and Macrophomina phaseolina $(90.41 \mathrm{~g} / 100 \mathrm{~g}$ protein) compared to uninoculated control $(93.23 \mathrm{~g} / 100 \mathrm{~g}$ protein). The amino acid composition of the infected and uninfected Jatropha seeds are presented in Table 1.

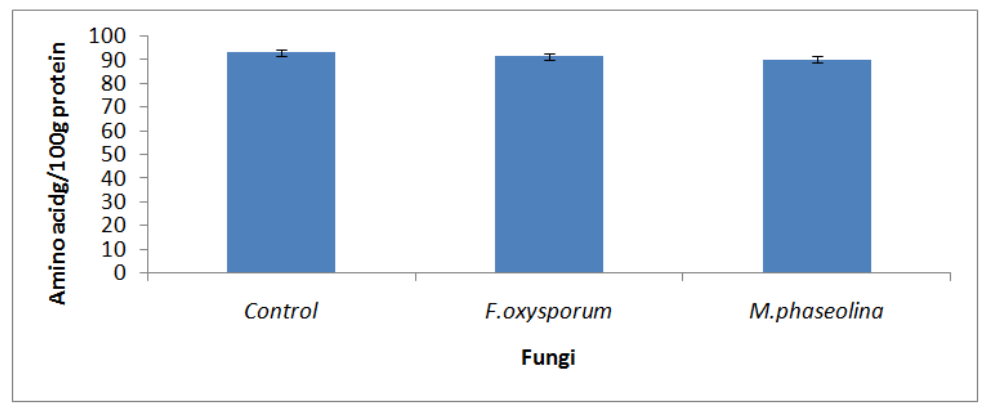

Fig 1: Total amino acid content of inoculated and uninoculated Jatropha curcas seeds

Table 1: Amino acid composition of Jatropha curcas seeds inoculated and uninoculated (g/100g protein)

\begin{tabular}{|l|l|l|l|}
\hline Amino acids & $\begin{array}{l}\text { Control } \\
\text { (uninoculated) }\end{array}$ & $\begin{array}{l}\text { Seeds inoculated } \\
\text { with F.oxysporum }\end{array}$ & $\begin{array}{l}\text { Seeds inoculated } \\
\text { with M.phaseolina }\end{array}$ \\
\hline Glycine & 4.18 & 4.49 & 4.04 \\
\hline Alanine & 4.44 & 4.02 & 4.29 \\
\hline Serine & 4.19 & 4.11 & 3.98 \\
\hline Proline & 4.08 & 3.97 & 3.96 \\
\hline Valine & 3.33 & 3.80 & 3.74 \\
\hline Threonine & 4.93 & 4.24 & 4.31 \\
\hline Isoleucine & 6.21 & 6.03 & 6.07 \\
\hline Leucine & 9.03 & 9.59 & 9.93 \\
\hline Aspartate & 9.45 & 9.43 & 8.82 \\
\hline Lysine & 4.40 & 4.47 & 4.06 \\
\hline Methionine & 1.93 & 1.40 & 1.29 \\
\hline Glutamate & 15.23 & 16.32 & 16.37 \\
\hline Phenylalanine & 4.18 & 4.15 & 3.96 \\
\hline Histidine & 3.24 & 2.16 & 2.21 \\
\hline Arginine & 10.01 & 8.44 & 9.06 \\
\hline Tyrosine & 2.92 & 3.32 & 3.06 \\
\hline Cystine & 1.48 & 1.65 & 1.26 \\
\hline
\end{tabular}




\section{Discussion}

In this study, the fungi, caused increases in protein when compared to the control. The significant increase $(\mathrm{P}=0.05)$ in protein content by Fusarium oxysporum and Macrophomina phaseolina could have resulted from slight protein synthesis of enzyme proteins or other constituents[10] (Kuo et al., 1995). Also the report of Burnett [11](1976) explained that the formation of proteases by molds during fermentation may result in increased protein amino acids. This result agrees with the report of [12] Nwaukwu and Ataga,(2012) on the "Biological changes in Hibiscus sabdariffa (Yakwa) seed induced by Aspergillus niger, Aspergillus flavus, Fusarium oxysporum, Penicillium chrysogenum and Penicillium rouqueforti. The two fungi had an effect on the amino acid component of the seed residue (Table 1).

There was significant reductions in amino acid contents in residue from seeds inoculated with F.oxysporum and Macrophomina phaseolina when compared to the uninoculated seeds. Eight (8) essential amino acids and nine (9) nonessential amino acids were analyzed with inoculated and uninoculated Jatropha curcas seeds. There was significant decrease in the four (4) essential amino acids Threonine, Isoleucine, Methionine, and Histidine when compared to the uninoculated control, while there was a significant increase in two (2) essential amino acid Leucine and Valine when compared to the uninoculated control of Jatropha curcas seeds. Two (2) nonessential amino acids Gluatamate and Tyrosine had significant increase when compared to the uninoculated control while (1) nonessential amino acid Arginine was significantly reduced when compared to the uninoculated control of Jatropha curcas seeds.

Lowered content of amino acids, with simultaneous increase in the quantity of crude protein was observed in the seeds inoculated with F.oxysporum and M.phaseolina. This may be attributed to the growth of the fungi at the expense of stored foodstuffs in the seeds so that seed protein becomes fungal protein of different amino acid composition. The relative levels of free amino acids of the Jatropha curcas seeds changed substantially as a result of the proteolytic enzymes of the test fungi and the utilization by the later of amino acid components as a source of nitrogen. Similar results were reported by [13] Cherry and Beuchat (1975) for peanuts inoculated with Rhizopus oligosporus, and [14]Ataga and Akueshi (1985) for sunflower seeds inoculated with Alternaria alternate,Curvularia lunata and Macrophomina phaseolina.

\section{Conclusion}

From this study, the growth of F.oxysporum and M.phaseolina on the seeds of Jatropha curcas increased the crude protein and altered the amount of total amino acid as compared to the uninoculated seeds. These result indicate that these fungi cause seed deterioration in altering the nutritional value and quality of Physic nut seeds.

\section{References}

[1]. Gubitz, G., Mittelbach, M. \& Trabi, M.(1999). Exploitation of the tropical oil seed plant Jatropha curcas L. Bioresource Technology, 67, 73-82.

[2]. Ghosh, A., Patolia, J., Chaudharry, D., Chikara, J., RAO, S., Kumar, D., Boricha, G. \& Zala, A.(2007). Response of Jatropha curcas under different spacing to Jatropha de-oiled cake.

[3]. Achten, W. M. J., Verchot, L., Franken, Y. J., Mathij S. E., Singh, V. P., Aerts, R. and Muys, B. (2008). Jatropha bio-diesel production and use. Biomass \& Bioenergy, 32, 1063-1084

[4]. Jongschaap, R., Corr , W., Bindraban, P. and Brandenburg, W.( 2007). Claims and Facts on Jatropha curcas L. Wageningen: Plant Research International.

[5]. Sharma K.D.( 1977). Biochemical changes in stored oilseeds. Ind.J. Agric. Res. 11: 137-141.

[6]. ISTA (1976). International Seed Testing Association. International Rules for Seed Testing. Seed Science and Technology 4: $51-77$.

[7]. Klement, Z. K. and Voros, I. C., (1974) Methods in Pathology. Elsevier Scientific Publishing Co., Amsterdam, London. Pp. 220288.

[8]. Ataga, A.E and Umechuruba, C.I( 1997). Biochemical changes in African Yam Bean seeds caused by Botryodiplodia theobromae, Fusarium palidoreseum and Penicillium oxalim. Global Journal of Pure and Applied Science 4(4): 381-384

[9]. Osborne and Voogt (1978). The analysis of nutrient in foods. Academic Press, London 159

[10]. Kuo, U.H., Bau, H.M., Quemener, B., Khan, J.K and Lambein, F (1995). Solid State fermentation of Lathyrus sativus seeds using Aspergillus oryzae and Rhizopus oligosporus SP T-3 to eliminate the neurotoxin B-ODAP without loss of nutritional value. Journal of Science, Food and Agriculture 69:81-8

[11]. Burnett, H.L and Hunter B.B (1976) Illustration Genera of imperfecti fungi (3 ${ }^{\text {rd }}$ edition). Burgess Publishing Company Minnesota

[12]. Nwaukwu I.A and A.E Ataga,(2012) Biochemical Changes induced by five Pathological Fungi on seeds of Hibiscus sadariffa (YAKWA) Scientia Africana.12 (1):1-6

[13]. Cherry, J.P and Beuchat, L.R. (1975) Comparative studies of protein and amino acid changes in peanuts infected with Neurospora sitophila and Rhizopus oligosporus. Cereal Chem. 53 (5) 750-761.

[14]. Ataga , A.E and Akueshi C.O (1985) Changes in protein and Amino acid composition of sunflower seed inoculated with Alternaria alternate, Curvularia lunata and Macrophomina phaseolina. Nigeria Journal of Biotechnology 2,45-49. 